REPORTS OF MORPHOLOGY
Official Journal of the Scientific Society of Anatomists,
Histologists, Embryologists and Topographic Anatomists
of Ukraine
journal homepage: https://morphology-journal.com

\title{
Pathophysiological model of indirect revascularization in rats with microangiopathy of limbs caused by experimental streptozocin diabetes
}

Vastyanov R.S., Chekhlova O.V.

Odessa National Medical University, Odessa, Ukraine

\section{ARTICLE INFO \\ Received: 3 September, 2019 \\ Accepted: 15 October, 2019}

UDC: $616.379-008.64: 616.137 .86 /$

.93-008.64:615.8

\section{CORRESPONDING AUTHOR}

e-mail: doctorchekhlova@gmail.com Chekhlova O.V.

\begin{abstract}
Despite the large number of publications, the model of experimental diabetes after the introduction of streptozotocin remains a subject of lively scientific debate. The purpose of this study was to develop a pathophysiological model of indirect revascularization in rats with microangiopathy of limbs caused by experimental streptozotocin diabetes. Experimental studies were carried out in a chronic experiment on 100 sexually mature Wistar rats weighing 180-250 g. The streptozotocin diabetes model used. After culling animals from increased resistance to pancreatotropic toxicity by the criterion of the absence of hyperglycemia, three experimental groups were formed: Group I (control) rats with streptozotocin-induced angiopathy without treatment $(n=10)$; II group - rats with streptozotocin-induced angiopathy treated with pentoxifylline (100 mg/kg IP for 10 days) for therapeutic purposes ( $n=25)$; III group - rats with streptozotocin-induced angiopathy, which together with the treatment were injected with platelet-rich plasma (in the right hind limb, once, with a volume of $0.2 \mathrm{ml}$, linearly, retrogradely, from two points) and pentoxifylline (100 mg/kg IP for 10 days) (n=25). The duration of the experiment was 110 days. We studied the level of glycemia, the state of microcirculation, and the degree of pathomorphological changes in the various study groups. Statistical processing was performed by non-parametric methods using software Statistica 10.0. The developed pathophysiological model of indirect revascularization with the introduction of pentoxifylline and plasma enriched with platelets in diabetic angiopathy is adequate to the needs of clinical physiology. It has been shown that the isolated administration of pentoxifylline is inferior to combined therapy by revascularizing activity. The results of the work may be an experimental justification for the feasibility of clinical application of the combination of pentoxifylline and platelets rich plasma in the treatment of diabetic angiopathy, as well as its use in prophylactic purposes in patients with diabetes mellitus.

Keywords: diabetes mellitus, diabetic angiopathy, pentoxifylline, platelets rich plasma, streptozotocin, experimental model.
\end{abstract}

\section{Introduction}

According to WHO definition, diabetes mellitus (DM) is called a non-communicable epidemic of the XXI century. In economically developed countries, $4-6 \%$ of people suffer from diabetes [20, 23]. In Ukraine, the incidence of diabetes, as in other countries in the world, is increasing every year. In Ukraine, 1270929 cases of diabetes were registered in 2017 , but the real spread of the disease is even higher according to experts, almost $50 \%$ of cases of diabetes have not been diagnosed [9].

Insulin-dependent diabetes is a serious condition that usually occurs in children and young people. Disease is the same often affects both men and women. The cause of insulin-dependent diabetes is autoimmune damage to the insulin-producing pancreatic $\beta$-cells. The incidence of the disease varies widely [18], the highest incidence rates are reported in Finland and Sardinia (more than 20 cases per 100,000 population per year) and the lowest in Asia (less than 3 cases per 100,000 population per year). Insulinindependent diabetes often occurs in adulthood. Risk factors are overweight, abuse of refined carbohydrates. It is this clinical form that is most common [20].

DM is one of the priority global problems for humanity today. According to experts, there are more than 200 million patients with diabetes in the world, with half of them not 
being diagnosed on time and manifesting complications, among which diabetic angiopathy is of great importance $[17,23]$.

The pathogenesis of diabetic angiopathy [19] remains the most pressing and complex problem in diabetology. The use of experimental models of diabetes is necessary both for the study of the pathophysiology of this disease and for the study of the anti-diabetic properties of new compounds [21], as well as the effect of transplantation of endocrine islets to diabetic animals, since it opens the possibility of studying clinical parameters before and after transplantation or treatment [1, 3, 4, 8, 10-12, 22].

Today, there are a large number of experimental models that allow to reproduce certain links of the pathogenesis of diabetes. These methods include, but are not limited to, DM models that are spontaneous or genetically derived, chemically induced, diet-induced, surgically, and more recently transgenic or knockout $[3,4,8]$.

For over 50 years, the only model of experimental diabetes has been diabetes caused by the removal of the pancreas. However, pancreatectomy requires a high level of surgical skill and adequate technical equipment. The operation results in traumatization of the animals and a high mortality rate. The high risk of infection requires postoperative antibiotic treatment [11]. In order to prevent absorption disorders in the intestine, it is necessary to replace the excretory functions of the gland. Regarding genetic modeling tools [7], the cost of one genetically modified rat today exceeds $15000 \mathrm{UAH}$, which makes it practically impossible to use them in the current state of science funding in Ukraine.

Due to the length of time and considerable resources required for most of these methods, chemically induced experimental DM remains the fastest and most economically viable option. After first reporting its ability to cause diabetes in 1963 [8], researchers have begun to widely use streptozotocin on animal models to study both the pathology of diabetes and the possible complications associated with the disease. Streptozotocin has the added benefit of being able to select specific traits of interest, since streptozotocin can induce diabetes in most rodent strains. This may be important for the study of islet transplantation, as specific immune responses or lack thereof may be critical for experimental design $[8,15,16]$.

For our experiments related to the study of the effects of different strategies of indirect revascularization in diabetic angiopathy, we decided to use the model with the introduction of streptozotocin.

Despite the large number of publications on this topic (over 18,000 titles for streptozotocin on PubMed as of $01 /$ $01 / 2019$ ), the model of experimental diabetes after the introduction of streptozotocin remains a subject of lively scientific debate. Critics of the method indicate that streptozotocin-induced diabetes does not fully reflect the pathogenesis of the disease in humans. In addition, this model gives a highly variable glycemic profile $[3,8,15]$.
There is no standard protocol for the drug, dose or administration of streptozotocin. Most of the literature to date contains very little detail of induction of diabetes in cases where target points are associated with its complications. This complicates the design process, does not allow you to correctly estimate the optimal sample sizes for experiments and set realistic graphics.

The purpose of this study was to develop a pathophysiological model of indirect revascularization in rats with microangiopathy of extremities on the background of experimental streptozotocin diabetes.

\section{Materials and methods}

Experimental studies were conducted under the conditions of a chronic experiment on 100 adult rats of the Wistar line weighing 180-250 g.

Following the administration of streptozotocin, animals with increased resistance to pancreatotropic toxicity were excluded from the experiment by the criterion for the absence of hyperglycemia, after which 2 animals were withdrawn for 6 weeks for morphological studies. At week 7 , another 10 animals were withdrawn from the experiment to evaluate the effectiveness of the experimental model. Of the remaining animals $(n=60)$, three experimental groups were formed.

Group I (control). Rats with streptozotocin-induced angiopathy without treatment $(n=10)$.

Group II. Rats with streptozotocin-induced angiopathy treated with pentoxifylline for therapeutic purposes (100 $\mathrm{mg} / \mathrm{kg}$ IP per day for 10 days $)(\mathrm{n}=25)$.

Group III. Rats with streptozotocin-induced angiopathy, which were co-administered with platelet-enriched plasma (in the right hind limb, one time, $0.2 \mathrm{ml}$ in volume, linear, retrograde, two-point) and pentoxifylline $(100 \mathrm{mg} / \mathrm{kg}$ IP per day for 10 days) $(n=25)$.

4 weeks after the start of experimental therapy, 5 animals were removed from the experiment. The total duration of the experiment was 110 days.

Animal preparation, all interventions, anesthetics and withdrawal from the experiment were carried out in full compliance with the requirements of the Guidelines of the State Pharmacological Center of the Ministry of Health of Ukraine (Kyiv, 2001), as well as the GLP rules provided by the European Commission for the supervision of laboratory and other studies, in accordance with Code of Scientist of Ukraine. Animal euthanasia was carried out in accordance with the provisions regulated by Annex 8 of the "Rules for the humane treatment of laboratory animals", "Sanitary rules for equipment, equipment and maintenance of experimental biological clinics (vivarium)" No. 1045-73.

Laboratory rats were kept in individual boxes with 12 hours of light and dark, humidity of $60 \%$, constant temperature of $22 \pm 10 \mathrm{C}$, with free access to water and food.

The experimental DM was reproduced in rats with intraperitoneal administration of streptozotocin $(60 \mathrm{mg} / \mathrm{kg}$; "Alfa Aesar", USA, [J61601, Lot: F30X011]), which was 
dissolved in sodium citrate buffer $(\mathrm{pH}=4.5)$.

The body weight of rats was determined in grams on special mechanical laboratory scales VL-120 (Tomsk, Russia), the error of the method was $\pm 100 \mathrm{mg}$.

Urine analysis was performed using Citolab 3GK diagnostic test strips, Pharmasco (Ukraine). Glucose and urine acetone were determined in $\mathrm{mmol} / \mathrm{l}$, and urine protein in $\mathrm{g} / \mathrm{l}$.

For the subsequent experiments, only those rats with blood glucose concentrations exceeding $12 \mathrm{mmol} / \mathrm{l}$ were selected. The simulation efficiency of the experimental DM was $92-95 \%$ (an average of only 1 rat out of 20 blood glucose concentrations at 2 days after streptozotocin administration was less than $10 \mathrm{mmol} / \mathrm{l}$ ).

Blood glucose content was determined using the glucosidase method [5].

Quantitative determination of glucose in the blood and urine, as well as acetone and urine protein in the first week after injection of the drug was determined on the 1st, 3rd and 7 th day, and then 1 time per week before the formation of experimental diabetic angiopathy (8 week).

The rats were observed for 8 weeks without treatment (this time interval was sufficient to form experimental diabetic angiopathy), after which treatment was started. Drugs for the treatment of rats with experimental diabetic angiopathy were administered starting at 53 days of the experiment.

The formation of experimental diabetic angiopathy was confirmed by morphological examination of the soft tissues of the hind paws of rats (to this end, 2 animals from each group were disposed of each week).

Platelet-enriched plasma was prepared according to the standard procedure [13], after preparation immediately injected into the right hind limb of rats of the third group with a volume of $0.2 \mathrm{ml}$ linearly retrograde from two points.

Statistical processing was performed by nonparametric methods using Statistica 10.0 software (Dell StatSoft Inc., USA)

\section{Results}

The average weight of animals involved in the study was $190.0 \pm 0.6 \mathrm{~g}$ at $\mathrm{c}_{\mathrm{v}}=2.9 \%$. When analyzing the distribution of blood glucose content in animals after the administration of streptozotocin, it was found that at an amplitude of 9.9$17.0 \mathrm{mmol} / \mathrm{l}$, this average was $14.23 \pm 0.21 \mathrm{mmol} / \mathrm{l}$. Further analysis showed that the simulation efficiency of the experimental DM was $92 \%$, which is acceptable for the subacute experiment [3].

Monitoring of the glycemic profile over 8 weeks showed a fairly stable glucose content with a tendency to increase (Fig. 1). This indicates a high risk of endothelial damage and the likelihood of developing specific complications for diabetes. On the other hand, these values indicate a low risk of hyperosmolar syndrome in experimental animals. Against the background of the experimental DM, the animals were lethargic, apathetic, with polydipsia and polyuria.

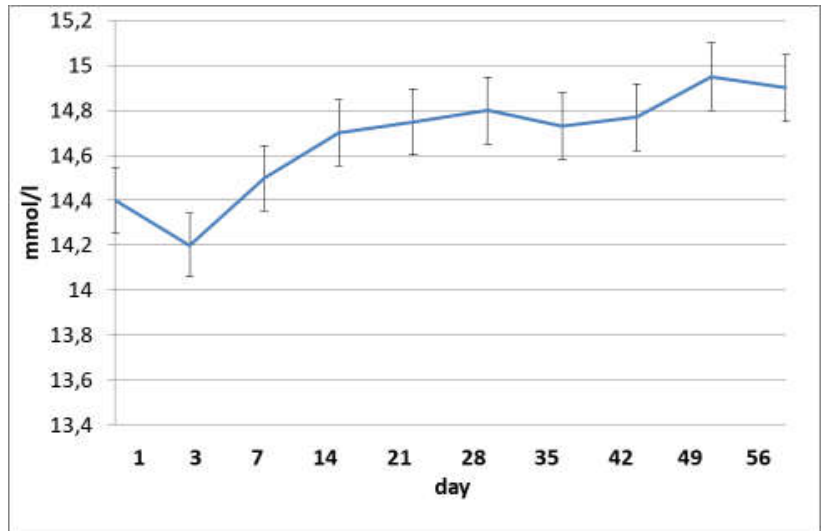

Fig. 1. The content of glucose in the blood of experimental animals within the first 8 weeks.

Table 1. State of microcirculation of distal segments of lower extremities of experimental animals, assigned to different groups $(\mathrm{M} \pm \mathrm{m})$.

\begin{tabular}{|c|c|c|c|}
\hline Indicator & I group & II group & III group \\
\hline $\begin{array}{c}\text { Perivascular infiltrate, } \\
\mu \mathrm{m}\end{array}$ & $7.932 \pm 0.812$ & $5.938 \pm 0.613^{*}$ & $3.624 \pm 0.312^{\star *}$ \\
\hline $\begin{array}{c}\text { The number of } \\
\text { microvessels, mm }{ }^{2}\end{array}$ & $3.714 \pm 0.211$ & $4.635 \pm 0.223^{* \star}$ & $4.828 \pm 0.214^{\star *}$ \\
\hline $\begin{array}{c}\text { The diameter of the } \\
\text { vessels, } \mu \mathrm{m}\end{array}$ & $7.736 \pm 0.723$ & $11.53 \pm 0.94^{* \star}$ & $11.62 \pm 0.61^{* \star}$ \\
\hline $\begin{array}{c}\text { Specific volume of } \\
\text { vessels of the } \\
\text { microcirculatory } \\
\text { bed, } \%\end{array}$ & $3.224 \pm 0.222$ & $3.941 \pm 0.312^{*}$ & $4.446 \pm 0.324^{* *}$ \\
\hline
\end{tabular}

Notes: ${ }^{*}$ - differences with the control group are statistically significant, $p<0.05 ;{ }^{* *}$ - differences with the control group are statistically significant, $p<0.01$.

The rapid analysis of glucose content in urine, as well as acetone and urine protein, showed rapid development of signs of diabetic nephropathy. By the end of the first week, urine protein excretion exceeded $25 \mathrm{mg}$ per day, averaging $25,74 \pm 0,42 \mathrm{mg} / \mathrm{day}$, and by the end of 2 months the observation had increased to $27,93 \pm 0,33 \mathrm{mg} /$ day. In terms of glucose content, in all experimental animals it exceeded $2 \%$, which corresponds to the average level $(11,14 \pm 0,31 \mathrm{Mmol} / \mathrm{l})$.

Quite high levels of proteinuria and glucosuria indicate impaired renal functional reserve resulting from dystrophy and partial necrosis of the distal tubule epithelium, mesangial cell proliferation, and moderate thickening of the vascular glomerular capillary membrane.

In $56.3 \%$ of cases, acetonuria, indicating the presence of ketoacidosis, was discovered by the qualitative method. However, the general condition of the animals suffered little, and the overall behavioral changes characteristic of the experimental DM predominated.

Diabetic angiopathy is characterized mainly by lesions of microcirculatory vessels, as evidenced by the results of our morphological studies of skin vessels. Thus, improving microcirculation can slow the development of diabetic angiopathy and, accordingly, improve the repair capacity of 
damaged tissues.

Thus, the severity of perivascular infiltrate was the lowest $(3.624 \pm 0.312 \mu \mathrm{m})$ in group III. This was 2.2 times less than that of rats with streptozotocin-induced diabetes $(p<0.01)$ and $39 \%$ less than rats with streptozotocininduced diabetes $(p<0.05)$.

The counts of the number of microvessels, their diameter and the specific volume of microcirculatory vessels were comparable in groups of rats with streptozotocin-induced diabetes treated with pentoxifylline and platelet-enriched plasma (Table 1).

\section{Discussion}

Thus, the experimental model created adequately reflects the features of diabetes of moderate severity in the stage of decompensation, which allows us to consider further conclusions regarding the course of diabetic angiopathy sufficiently substantiated.

As shown by our studies, rats of group I underwent significant changes in all layers of the skin, which were partially offset by the use of experimental therapy aimed at indirect revascularization of ischemic tissues.

The results showed that in the condition of reproduction of diabetes, after 6 weeks, a typical picture of diabetic angiopathy develops in rats. In addition to dystrophic changes in the skin, the animals had phenomena of diabetic peripheral polyneuropathy, which was manifested by weakness of the extremities and diminished reflex response to tingling irritation [11]. There were also signs of temperature hyperalgesia.

We consider it worth mentioning that the positive effects of indirect revascularization can be explained by the influence and pathogenesis of diabetic angiopathy, such as inflammation (increase in fibrinogen, C-reactive and protein amyloid-1, cytokines) [1, 12], oxidative stress (increasing the content of reactive oxidants and simultaneously reducing the functional activity of the enzymatic and non-enzymatic units of the antioxidant system), the reduction of the activity of NO synthase and the activity of nitrergic mechanisms [7], disorders of the hemocoagulation [10-12], vascular dysfunction of the microcirculatory bed $[3,16]$.

The important question is what is the mechanism of realization of the protective effect of pentoxifylline and its combination with platelet-enriched plasma under model conditions? According to the literature [16], the following effects are indicative of pentoxifylline: inhibition of phosphodiesterase activity and cAMP accumulation in myocytes of the smooth muscle layer of blood vessels, blood cells, as well as in other tissues and organs; inhibition of erythrocyte and platelet aggregation; increasing the flexibility of erythrocytes and, accordingly, their ability to pass through capillaries; reduction of increased plasma fibrinogen concentration and increased fibrinolysis. In addition, pentoxifylline has a weak myotropic vasodilator effect, which leads to a decrease in overall peripheral vascular resistance. Pentoxifylline also has a positive inotropic effect, improves microcirculation and reduces the oxygen debt of peripheral tissues $[4,6,16]$. In addition, pentoxifylline has a potent anticytokine effect that allows a number of researchers to view this drug as a component of pathogenetic therapy for systemic inflammatory responses [6, 16, 17].

The immunomodulatory properties of pentoxifylline are mediated as a direct inhibition of the production of tumor necrosis factor (TNF- $\alpha$ ) and a number of other cytokines (interleukins-1, -2, -6 and $y$-interferon) [16], as well as by influencing chemotaxis and migration, leukemia adhesion of endothelial leukocytes, reduction of degranulation and excretion of superoxides in neutrophils, reduction of leukocyte sensitivity to interleukin and TNF- $\alpha$ inhibition of T and $B$ lymphocyte activity, as well as NK cells [9, 16-18, 20, 23].

It should be noted that the endotheliumprotective effect of pentoxifylline is also partly explained by the decrease in the activity of TNF- $\alpha$. In addition, pentoxifylline also protects endothelial cells from the harmful effects of neutrophil leukocytes by eliminating the effect of platelet activation factor on granulocytes $[1,16]$.

Pentoxifylline has various effects on the blood. Various in vitro and in vivo models have demonstrated its ability to suppress thrombus formation processes. Reduction of platelet aggregation under the influence of the drug can be associated with both direct inhibition of phosphodiesterase of the platelet membrane, which catalyzes the conversion of cAMP to AMP [16], and to stimulate the secretion of prostacyclin [1, 16].

Pentoxifylline and its metabolites affect blood clotting and fibrinolysis: stimulate the secretion of tissue plasminogen activator (tPA) and reduce the concentration in the blood of its inhibitors, slow the secretion of the Von Willebrand factor, increase the levels of plasmin and antithrombin-3 $[6,16]$. However, despite the very wide range of effects, the effect on microcirculation in the application of pentoxifylline is due primarily to the effect on blood rheology and the precapillary element of the vascular system [16].

Instead, platelet-rich plasma has a slightly wider range of effects. Platelets contain granules that can secrete into the environment a significant number of biologically active compounds, both with procoagulative activity and those that affect cell proliferation and modulate inflammation processes. Even 30 years ago, platelets were considered mainly in terms of their participation in the coagulation system, but it is now known that platelets contain growth factors and a large number of cytokines that can affect inflammation, angiogenesis, cell migration and cell proliferation [2, 9, 14].

Platelet-rich plasma is a powerful natural source of signaling molecules. Upon activation of platelets contained in platelet-enriched plasma, a significant amount of biologically active raw material capable of modifying the pericellular microenvironment is secreted. Some of the 
growth factors secreted by platelet-enriched plasma have a direct effect on cell proliferation processes. The most important growth factors are vascular endothelial growth factor, fibroblast growth factor, platelet growth factor itself, epidermal GF, hepatocyte growth factor, insulin-like growth factors type 1 and 2 (IGF-1, IGF-2). In addition, platelets secrete matrix metalloproteinases 2 and 9 , interleukin- 8 [2].

In fact, platelet-enriched plasma is a plasma fraction of autoblood with platelet concentrations above baseline (before centrifugation) [2, 17]. Thus, platelet-rich plasma contains not only a high platelet count but also a complete set of blood coagulation factors, as well as chemokines, cytokines and other plasma proteins [14]. Thus, the introduction of platelet-rich plasma not only stimulates cell proliferation, promoting repair and regeneration of damaged tissues, but also influences angiogenesis, enhancing the formation of new vessels and promoting the preservation of the existing vascular network. All this has a positive effect on microcirculation.

The introduction into the damaged tissues of plateletenriched plasma allows to cause the aggregation of inflammatory cells through the release of chemotactic, angiogenic and mitogenic growth factors. Increasing macrophage migration plays a significant role. During the proliferative phase of healing, macrophages accumulate in

\section{References}

[1] Agrawal, N. K., \& Kant, S. (2014). Targeting inflammation in diabetes: Newer therapeutic options. World Journal of Diabetes, 5(5), 697-710. doi: 10.4239/wjd.v5.i5.697

[2] Ahmed, M., Reffat, S. A., Hassan, A., \& Eskander, F. (2017). Platelet-rich plasma for the treatment of clean diabetic foot ulcers. Annals of Vascular Surgery, 38, 206-211. doi: 10.1016/ j.avsg.2016.04.023

[3] Al-Awar, A., Kupai, K., Veszelka, M., Szücs, G., Attieh, Z., Murlasits, Z., ... Varga, C. (2016). Experimental diabetes mellitus in different animal models. Journal of Diabetes Research, 2016, 9051426. doi: 10.1155/2016/9051426

[4] Barrett, E. J., Liu, Z., Khamaisi, M., King, G. L., Klein, R., Klein, B. E., ... Vinik, A. I. (2017). Diabetic microvascular disease: an endocrine society scientific statement. The Journal of Clinical Endocrinology \& Metabolism, 102(12), 4343-4410. doi: 10.1210/jc.2017-01922

[5] Chyrkyn, A. A. (2002). Workshop on Biochemistry. Mn.: New knowledge.

[6] Elraiyah, T., Tsapas, A., Prutsky, G., Domecq, J. P., Hasan, R., Firwana, B., ... Steinkraus, L. W. (2016). A systematic review and meta-analysis of adjunctive therapies in diabetic foot ulcers. Journal of Vascular Surgery, 63(2), 46S-58S. doi: 10.1016/j.jvs.2015.10.007

[7] Fenske, R. J., Cadena, M. T., Harenda, Q. E., Wienkes, H. N., Carbajal, K., Schaid, M. D., ... Wisinski, J. (2017). The Inhibitory G Protein a-Subunit, Gaz, Promotes Type 1 Diabetes-Like Pathophysiology in NOD Mice. Endocrinology, 158(6), 16451658. doi: 10.1210/en.2016-1700

[8] Furman, B. L. (2015). Streptozotocin induced diabetic models in mice and rats. Current Protocols in Pharmacology, 70(1), 547. doi: 10.1002/0471141755.ph0547s70

[9] Germanyuk, T. A., Ivko, T. I., \& Bobrytska, L. O. (2018). The the damaged site and realize either a pro-inflammatory or anti-inflammatory phenotype. M1 macrophages actively phagocytize, destroying damaged cells and microorganisms; they are capable of recruiting additional reparative cells (eg, myofibroblasts), and promote the release of proinflammatory cytokines. M2 macrophages promote angiogenesis, affect the restoration of the soft tissue connective tissue framework, affecting remodeling and ultimately, scar tissue formation. These macrophages mainly produce anti-inflammatory cytokines [9]. Both phenotypes play important roles in reparative processes, affecting angiogenesis, differentiation of fibroblasts and collagen formation $[9,17]$.

\section{Conclusions}

1. The developed pathophysiological model of indirect revascularization with the introduction of pentoxifylline and platelet-rich plasma in diabetic angiopathy is adequate to the needs of clinical physiology.

2. Isolated administration of pentoxifylline by revascularizing activity is inferior to combination therapy.

3 . The results of the work may be an experimental justification for the clinical utility of the combination of pentoxifylline and platelet-enriched plasma in the treatment of diabetic angiopathy, as well as its use for prophylactic purposes in patients with diabetes.

study of the effectiveness of the combined therapy of diabetes mellitus based on the pharmacoeconomic analysis in Ukraine. Pharmacy Bulletin, (3), 49-53. doi: 10.24959/nphj.18.2214

[10] Heinonen, S. E., Genové, G., Bengtsson, E., Hübschle, T., Åkesson, L., Hiss, K., ... Gomez, M. F. (2015). Animal models of diabetic macrovascular complications: key players in the development of new therapeutic approaches. Journal of Diabetes Research, 2015, 404085. https://doi.org/10.1155/ 2015/404085

[11] King, A., \& Bowe, J. (2016). Animal models for diabetes: understanding the pathogenesis and finding new treatments. Biochemical Pharmacology, 99, 1-10. doi: 10.1016/ j.bcp.2015.08.108

[12] King, A. J. (2012). The use of animal models in diabetes research. British Journal of Pharmacology, 166(3), 877-894. doi: 10.1111/j.1476-5381.2012.01911.

[13] Kopchak, O. V., Biloklytska, G. F., Rozdobudko, N. I., \& Dieiev, V. A. (2017). A method of obtaining platelet-enriched plasma of venous blood. Patent $119951 \mathrm{U}$, Ukraine.

[14] Martinez-Zapata, M. J., Martí Carvajal, A. J., Solá, I., Expósito, J. A., Bolíbar, I., Rodríguez, L., ... Zaror, C. (2016). Autologous platelet rich plasma for treating chronic wounds. Cochrane Database of Systematic Reviews, (5), CD006899. doi: 10.1002/ 14651858.CD006899.pub3

[15] Mazo, V. K., Sidorova, Yu. S., Zorin, S. N., \& Kochetkova, A. A. (2016). Streptozotocin models of diabetes mellitus. Problems of Nutrition, 85(4), 14-21.

[16] Mokhort, T. V. (2015). Chronic complications of diabetes mellitus: focus on pentoxifylline. Medical News, 4(247), 4-9.

[17] Pérez-Díaz, I. (2016). Diabetes mellitus. Gac Med Mex, 152(1), 50-55.

[18] Polsky, S., \& Ellis, S. L. (2015). Obesity, insulin resistance, and 
type 1 diabetes mellitus. Current Opinion in Endocrinology, Diabetes and Obesity, 22(4), 277-282. doi: 10.1097/ MED. 0000000000000170

[19] Shved, M. I., Dudnik, A. P., \& Zhulkevych, I. V. (1998). Pathogenetic aspects of formation of diabetic angiopathies. Bulletin of Scientific Researches, (1-2), 56-58.

[20] Tao, Z., Shi, A., \& Zhao, J. (2015). Epidemiological perspectives of diabetes. Cell biochemistry and biophysics, 73(1), 181185. doi: 10.1007/s12013-015-0598-4

[21] Vainshtein, S. G., Zhulkevich, I. V., Petropavlovskii, G. A., \& Kotel'nikova, N. E. (1987). Protective properties of microcrystalline cellulose in rats with experimental diabetes. Bulletin of Experimental Biology and Medicine, 103(2), 186188. PMID: 3028529

[22] Vainstein, S. G., Zhulkevich, I. V., Dubkin, M. S., \& Cherno, N. K. (1987). Food fibers as modifiers of homeostasis in patients with diabetes mellitus. Therapeutic Archive, 59(11), $29-31$.

[23] Wild, S., Roglic, G., Green, A., Sicree, R., \& King, H. (2004). Global prevalence of diabetes: estimates for the year 2000 and projections for 2030. Diabetes Care, 27(5), 1047-1053. doi: 10.2337/diacare.27.5.1047

\section{ПАТОФІЗІОЛОГІЧНА МОДЕЛЬ НЕПРЯМОЇ РЕВАСКУЛЯРИЗАЦІЇ У ЩУРІВ 3 МІКРОАНГІОПАТІЄЮ КІНЦІВОК НА ТЛІ ЕКСПЕРИМЕНТАЛЬНОГО СТРЕПТОЗОЦИНОВОГО ДІАБЕТУ \\ Вастьянов Р.С., Чехлова О.В.}

Незважаючи на велику кількість публікацій, модель експериментального цукрового діабету після введення стрептозоцину залишається предметом жвавої наукової дискусії. Метою даного дослідження була розробка патофьізіологічної моделі непрямої реваскуляризації у щурів з мікроангіопатією кінцівок на тлі експериментального стрептозоцинового діабету. Експериментальні дослідження були проведені за умов хронічного експерименту на 100 статевозрілих щурах лінії Вістар масою 180-250 г. Використали стрептозоцинову модель діабету. Після вибракування тварин із підвищеною резистентністю до панкреатотропної токсичної дії за критерієм відсутності гіперглікемії, сформовано три експериментальні групи: I група (контроль). Щури із стрептозотоцин-індукованою ангіопатією без лікування ( $n=10)$; II група - щури зі стрептозотоциніндукованою ангіопатією, яким з лікувальною метою вводили пентоксифілін (100 ме/кг в/очеревинно щоденно протягом 10 днів) (n=25); III група - щури зі стрептозотоцин-індукованою ангіопатією, яким з лікувальною метою сумісно вводили збагачену тромбоцитами плазму (в праву задню кінцівку одноразово, об'ємом 0,2 мл, лінійно ретроградно з двох точок) та пентоксиорілін (100 мг/кг в/очеревинно щоденно протягом 10 днів) (n=25). Загальна тривалість експерименту склала 110 днів. Досліджували рівень глікемії, стан мікроциркуляиії та ступінь патоморфологічних змін у різних групах дослідження. Статистичну обробку проводили непараметричними методами за допомогою програмного забезпечення Statistica 10.0. Розроблена патофрізіологічна модель непрямої реваскуляризації з введенням пентоксифріліну та плазми, збагаченої тромбоцитами при діабетичній ангіопатії є адекватною потребам клінічної фізіології. Показано, що ізольоване введення пентоксифіліну за реваскуляризуючою активністю поступається комбінованованій терапії. Результати роботи можуть бути експериментальним обгрунтуванням доцільності клінічного застосування комбінації пентоксифріліну та плазми збагаченої тромбоцитами при лікуванні діабетичної ангіопатії, а також їх застосування з профрілактичною метою у хворих на иукровий діабет.

Ключові слова: цукровий діабет, діабетична ангіопатія, пентоксифрілін, плазма збагачена тромбоцитами, стрептозоцин, експериментальна модель.

\section{ПАТОФИЗИОЛОГИЧЕСКАЯ МОДЕЛЬ НЕПРЯМОЙ РЕВАСКУЛЯРИЗАЦИИ У КРЫС С МИКРОАНГИОПАТИЕЙ КОНЕЧНОСТЕЙ НА ФОНЕ ЭКСПЕРИМЕНТАЛЬНОГО СТРЕПТОЗОЦИНОВОГО ДИАБЕТА \\ Вастьянов Р.С., Чехлова Е.В.}

Несмотря на большое количество публикаций, модель экспериментального сахарного диабета после введения стрептозоцина остается предметом оживленной научной дискуссии. Целью данного исследования была разработка патофизиологической модели непрямой реваскуляризации у крыс с микроанаиопатией конечностей на фооне экспериментального стрептозоцинового диабета. Экспериментальные исследования были проведены в условиях хронического эксперимента на 100 половозрелых крысах линии Вистар массой 180-250 г. Использована стрептозоциновая модель диабета. После выбраковки животных с повышенной резистентностью к панкреатотропному токсическому действию по критерию отсутствия гипергликемии, сформированы 3 экспериментальные группы: I группа (контроль), крысы со стрептозотоцин-индуцированной ангиопатией без лечения составили II группу (n=10); крысы со стрептозотоцининдуцированной ангиопатией, которым с лечебной целью вводили пентоксифиллин (100 мг/кг в/брюшинно в течение 10 дней) (n=25) составили III группу. Крысы со стрептозотоцин-индуцированной анаиопатией, которым с лечебной целью совместно вводили обогащенную тромбоцитами плазму (в правую заднюю конечность однократно 0,2 мл, линейно, ретроградно, из двух точек) и пентоксифиллин (100 мг/кг в/брюшинно в течение 10 дней) (n=25). Длительность эксперимента составила 110 дней. Исследовали уровень гликемии, состояние микроциркуляции и степень патоморфологических изменений в различных группах исследования. Статистическую обработку проводили непараметрическими методами с помощью программного обеспечения Statistica 10.0. Разработанная патофизиологическая модель непрямой реваскуляризации с введением пентоксифиллина и плазмы, обогащенной тромбоцитами при диабетической ангиопатии является адекватной потребностям фризиологии. Показано, что изолированное введение пентоксифиллина по реваскуляризирующей активности уступает комбинированованной терапии. Результаты работы могут быть экспериментальным обоснованием целесообразности клинического применения комбинации пентоксифиллина и плазмы, обогащенной тромбоцитами при лечении диабетической ангиопатии, а также их применения с профилактической целью у больных сахарным диабетом. Ключевые слова: сахарный диабет, диабетическая ангиопатия, пентоксифиллин, плазма обогащенная тромбоцитами, стрептозоцин, экспериментальная модель. 